\title{
Financial Risk, Innovation and Alternative Pathways to Decarbonising the Energy System in 2050
}

\author{
Ivan Diaz-Rainey* \\ Environmental and Energy Finance Group (EEFG) \& Norwich \\ Business School, University of East Anglia, UK. \\ E-mail: i.diaz-rainey@uea.ac.uk \\ Daniel J. Tulloch \\ Environmental and Energy Finance Group (EEFG) \& Norwich \\ Business School, University of East Anglia, UK. \\ * Corresponding author
}

\begin{abstract}
There is a lot of forward looking work attempting to envisage the decarbonised energy system of the future as reflected with current interest in 'smart grids'. A central tenet behind most visions of the 'smart grids' of the future are the price signals that financial and commodity markets will deliver to facilitate effective and efficient resource allocation. Most of these visions take stylised and static views of financial and commodity markets despite the fact that these markets are experiencing dramatic change due to innovation and regulation. Accordingly, the paper maps the risks associated in the fusion of financial innovation with innovation in the energy system through a theoretical framework that draws on evolutionary models of paradigm shift. Risks to both the financial and energy systems are characterised as either emanating from primary or secondary markets and these are explored in terms of alternative visions of the energy system in the long run.
\end{abstract}

Keywords: Innovation; Financial Crisis; Energy Markets; Smart Grids; Energy Policy.

\section{Introduction}

The paper builds on earlier work (Diaz-Rainey et al., 2011) which explored the financial regulation of wholesale energy and environmental markets. Diaz-Rainey et al. 2011, however, focused on the energy system and energy markets as they currently are rather as to how they are envisaged. This paper, by way of contrast, maps financial risk in the energy system of the future (e.g. in 2050). This is done through a theoretical framework that draws on qualitative evolutionary models of paradigm shift (e.g. Anderson and Tushman, 1990; Dosi, 1982) and in the context of the established literatures on financial innovation and financial crises (e.g. Allen et al., 2009; Garber, 1990; Van Horne, 1985). The paper should, therefore, be of interest to academics, practitioners, regulators and policymakers in as much as it helps to frame the issues. More generally, the research is relevant to the fight against climate change and will appeal to a broad range of academic audiences including those focussed on: innovation; financial regulation; sustainable development; energy policy; and energy modelling. 


\section{Energy system context}

In response to high fossil fuel prices and growing concerns about climate change, new energy production and consumption paradigms have been advocated. Despite contrasting visions, techno-market approaches dominate (EU Commission, 2011; Jørgensen, 2005; US DOE, 2009; Verbong and Geels, 2010) where the interaction between markets and technological innovation, such as smart appliances, smart grids and electric vehicles are envisaged. This approach emphasises price signals as central to directing change within the energy system, not only altering the energy mix and moving supply from fossil fuels towards renewable energy, but also in creating more demand responsive consumers.

There is a good deal of forward looking work attempting to envisage the decarbonised energy system of the future as reflected with current interest in 'smart grids' (e.g. Battaglini et al., 2009; EU Commission, 2011; US DOE, 2009). Smart grids can be understood as the marrying of ICT technologies to the electricity grid in order to facilitate an electricity system that allows for demand responsive consumers and effectively integrates renewable generation and new consumer technologies such as electric vehicles (See Figure 1 for a depiction of a smart grid and Figure 2 for overview of the companies involved in smart grid development).

As noted above, a central tenet behind most visions of the 'smart grids' of the future are the price signals that energy markets will deliver to facilitate effective and efficient resource allocation. Hence, smart consumers will charge their electric vehicles when prices are lowest and feedback to the grid when they are very high. Most of these visions take stylised views of (energy) markets consistent with the assumption of perfect competition in neo-classical economics (frictionless markets, perfect information etc). Markets rarely work this way with a myriad of departures from the classical model (low liquidity, counterparty risk, financial contagion and speculative bubbles) likely to create unanticipated risks.

\section{Financial system context}

Currently financial markets are experiencing dramatic change due to innovation and regulatory changes (see Hendershott et al., 2011; Haldane, 2010; O'Hara and Ye, 2011). High Frequency Trading and increasingly integration have made markets increasingly responsive and volatile. Exchange Traded Funds mean that retail investors have access to any asset class they wish to invest in (be it commodities, venture capital or hedge funds). Technology and deregulation have meant organised exchanges are having their market shares eroded by cheaper Alternative Trading Systems posing real challenges for financial regulation.

Further, the functioning of commodity and energy markets is currently the source of considerable interest among policymakers, regulators, academics and industry practitioners. Rising commodity market prices generally and in particular high oil prices have triggered a debate as to the role of 'speculation' in commodity markets. The concern is that financial investors are causing commodities to overshoot their market fundamentals. Accordingly, though the increased participation of institutional (including High Frequency Traders) and individual (through Exchange Traded Funds) investors in commodity markets is beyond doubt, what remains open to contrasting assessments and opinion is their impact on price formation (Buyuksahin and Harris, 2011, Diaz-Rainey et al., 2011; Lombardi and Van Robays, 2011; Turner et al., 2011). Indeed, there is some 
anecdotal evidence of new risks emerging from the fusion of financial innovation with the increasingly marketised energy system. For instance, it is believed that prior to its collapse Amaranth Advisors LLC, an energy focussed hedge fund, played a major role in destabilising the gas market in 2006 (Levine and Coleman, 2007).

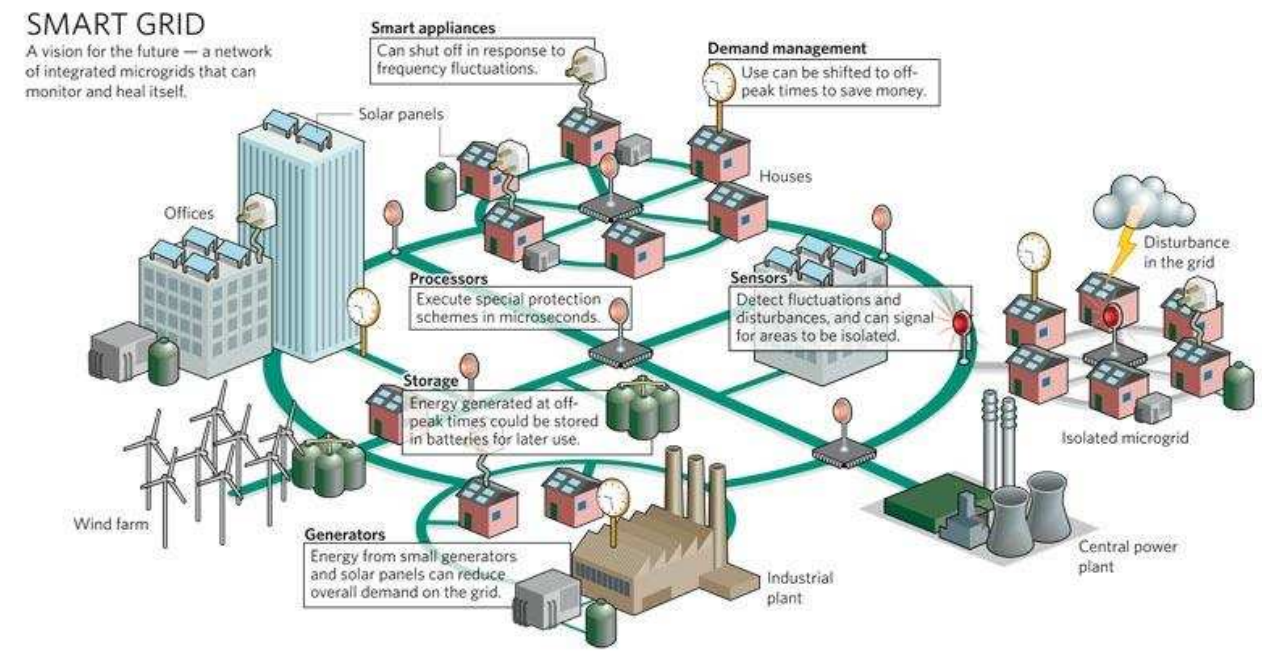

Figure 1 Energy Smart Grid

(Source: Smart Grid 2030)

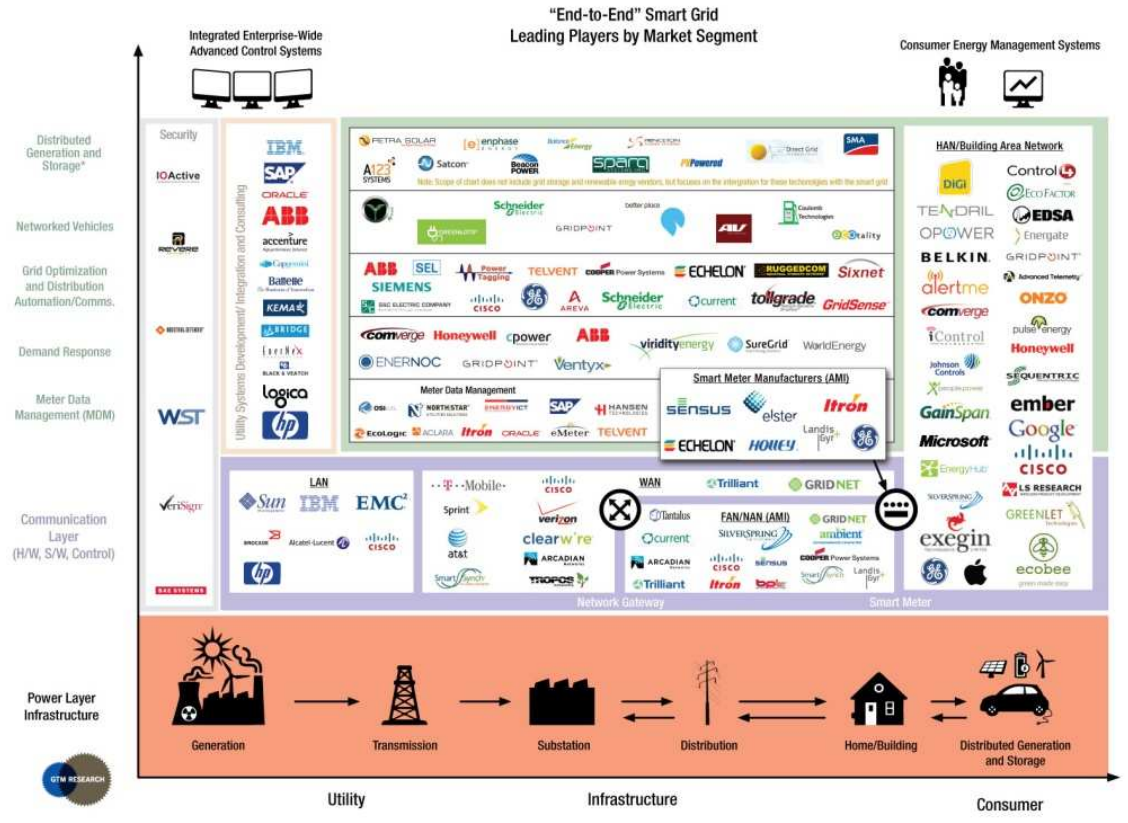

Figure 2 Companies involved in Smart Grid development

(Source: GreenTech Media) 


\section{Research question and paper structure}

From the preceding discussion it is clear that the process of innovation in the energy system has coincided with financial innovation and turbulence in global financial and commodity markets. This paper explores potential risks arising from the fusion of innovations from two 'systems' (or sectors), namely the financial system and the energy system as both sectors evolve. The paper, therefore, addresses the following question: What are the financial and financially-induced energy policy risks associated with the emergence of Decarbonised-Techno-Market Energy Systems in the broader context of rapid financial innovation? In order to answer this question the paper is structured as follows; section 2 provides a review of the established literatures on financial innovation and financial crises, section 3 outlines the theoretical framework, while section 4 maps the financial risks associated in the fusion of financial innovation with innovation in the energy system. Section 5 provides concluding remarks, including policy recommendations and suggestions for further research.

\section{Literature review: Technological and financial innovation, crises and risk}

Financial crises are increasing in frequency (Bordo et al., 2001). This should be an issue of concern as the energy system is increasingly 'marketised'. Accordingly the established literatures on financial crises (2.1) and past work addressing relationship technological and financial innovation and financial risk are reviewed (2.2).

\subsection{Financial crises}

Each financial crisis is unique but certain underlying causes tend to recur. In this respect it is useful to reflect on the causes, the nature and the consequences of financial crises.

A factor common in many crises is the bursting of speculative bubbles which are often in turn associated with innovation, be it technological or financial (See 2.2 below and Perez, 2009). Hindsight tends to interpret speculative bubbles as 'pathologies of group psychology' which may neglect the role legitimate bull market fundamentals play in driving investors' behaviour (Garber, 1990). Accordingly, bull market fundamentals can lead to a situation of 'strategic complementarity' where investors second-guess each others' attempts to benefit from the market fundamentals by investing in an attempt to benefit from the anticipated investment of others'. This ultimately leads to a speculative bubble.

Financial crises are also associated with; (1) excessive risk taking as reflected in the use of leverage in its many guises (direct loans, use of derivatives etc), which in turn can often be associated with loose monetary policy; (2) intense competition can lead to efficient market outcomes in the short term but can leave institutions/market participants unable to withstand adverse market shocks or conditions (Allen and Gale, 2004); (3) fraud and firm failures; and (4) regulatory failure which is perhaps most clearly highlighted in the context of the recent credit crunch of 2007-2008 by the limitations of the 'backward looking' risk assessments that BASEL II accord permitted when evaluating bank capital adequacy (Goddard et al., 2009).

Turning to the nature of crises, it is well established that during crises correlations between assets increase as investors become indiscriminately risk averse leading to contagion to markets which may not have any fundamental or underlying problem (Baig and Goldfajn, 1999). Further, it would seem that the dual effects of (1) technology 
'speeding up' finance and (2) the spreading of risk through financial innovation and increasingly integrated financial markets, has meant that the likelihood of financial contagion is higher than ever (Allen et al., 2009; Haldane, 2010). The effects of crises include loss of confidence in markets, systemic threats and can have real (macro) economic costs, though all of these must be balanced against the costs of regulation.

\subsection{Speculative bubbles and innovation}

As noted above, financial crises are also associated with innovation. Van Horne (1984) argues that it is not the financial innovations per se that are the problem, rather it can be unscrupulous schemes masquerading as such that cause the real difficulties, though ex ante differentiation of the two is not easy. Further, the 'dot.com'/telecoms bubble and the recent 'credit crunch' have led to renewed examinations of the interactions between innovation, technological paradigms and financial crises from a neoSchumpeterian/evolutionary perspective. For instance, Perez (2009) distinguishes between bubbles driven by technological innovation and those driven by financial conditions (excessive liquidity), noting that the former tend to occur mid-way through a technological paradigm shift. Both Perez (2009) and Kam (2006) observe that though bubbles driven by changing technological paradigms may cause severe economic dislocations they are part of a natural Schumpeterian economic phenomenon of 'creative destruction'. Fransman (2004, p.405) concurs but suggests how some of the more dramatic excesses may be dampened by producing "greater variety in thinking" so as to challenge inflated 'Consensus Visions'. This adds to the long established recommendations in this area related to effective financial regulation and adequate knowledge of financial history (Galbraith, 1954).

\section{Theoretical framework: Evolutionary models of paradigm shift}

As noted in the introduction, this paper addresses the following question: What are the financial and financially-induced energy policy risks associated with the emergence of Decarbonised-Techno-Market Energy Systems in the broader context of rapid financial innovation? Accordingly the next section provides a qualitative conceptualisation of the risks associated in the fusion of financial innovation with innovation in the energy system through a theoretical framework that draws on qualitative evolutionary models of paradigm shift (see below) and in the context of the established literatures on financial innovation and financial crises (reviewed in Section 2).

\subsection{Models of paradigm shift}

"A paradigm is thus a collectively shared logic at the convergence of technological potential, relative costs, market acceptance, functional coherence and other factors." Perez (2010, pp.186-187)

Perez (2010) provides a review of the established models of technological paradigm shift. These models have Schumpeterian roots and including work by Anderson and Tushman (1990), Dosi (1982) and Geels and Schot (2007). For instance, Anderson and Tushman (1990) provide a model of technological paradigm shift at the industrial level triggered by 
a technological 'discontinuity', while Geels and Schot (2007) present an increasingly utilised multi level perspective with alternative transition pathways.

These general models of paradigm shift have been complemented by research focussing on transition in the energy sector (See Section 3.2, below) and by work emphasising finance and financial markets as important yet imperfect selection mechanisms (Fransman, 2004; Dosi and Nelson, 1994). The notion of finance as an important selection mechanism is a complement to the improved understanding of the interplay between innovation, technological paradigms and financial crises discussed earlier (See Section 2.2).

\subsection{Alternative visions for the energy system of the future}

Some of the key attributes of the energy system of the future include (see Figure 1; US DOE, 2009; Valocchi et al., 2010; Verbong and Geels, 2010):

- Efficient, green and secure energy: Efficient and secure allocation of decarbonised energy enabled by energy markets and ICT innovations including hardware and software (See Figure 2).

- New energy market participants and services: An increased emphasis on energy services rather than energy consumption with new $3^{\text {rd }}$ party market participants intermediating (often referred to as Aggregators and/or Energy Services Companies (ESCOs)) between the energy system/market and end users.

- Demand side management and price responsive consumers: Enabled by technological innovations such as smart appliances and smart meters, as well as the aforementioned 'Aggregators' and their new services.

- Integration of renewables: In particular intermittent wind generation.

- Energy storage: Storage is again expected to be facilitated by technological innovation such as improved battery technologies.

- Integration of Electric Vehicles (EV): Increasingly EVs are seen not just as a drain on the system but as an intergraded component for balancing due to the possibility of using EV batteries as a form of energy storage that can feedback into the grid (US DOE, 2009).

- 'Prosumers': Consumers being also producers give small scale generating technologies such as photovoltaic generation and small scale wind turbines. The ability to be a 'prosumers' is enabled by technologies such as bi-directional smart meters.

Most visions of the future share these attributes, however, there are contrasting configuration of the future end state of the energy system within the boundaries of these attributes (Battaglini et al., 2009; Foxon et al., 2010; Verbong and Geels, 2010).

These contrasting visions have been articulated using evolutionary models of paradigm shift (Verbong and Geels, 2010; Foxon et al., 2010). For instance, Verbong and Geels (2010) apply the Geels and Schot (2007) multi level approach with alternative transition pathways to energy sector paradigm change. Specifically they identify three transition pathways (TPs) which are described in Table 1 and which are assessed with respect to the degree of 'network change' they imply relative to the existing network configuration and the principal 'dynamic' driving change.

Although the TPs differ in terms of how radical they are with respect to network configuration, all three require large scale investment (Verbong and Geels, 2010, p.1219). 
Further, though Verbong and Geels (2010) and Foxon et al. (2010) provide enlightening panoramas of the future they do not considered finance and financial markets in detail. The presumption is that the financing needed for whichever pathway is taken will be delivered. As noted earlier finance and financial markets are a critical yet imperfect enabler and selection mechanism (Section 3.1).

Table 1 Alternative visions for the energy system in the long term

\begin{tabular}{|c|c|c|c|}
\hline $\begin{array}{l}\text { Transition } \\
\text { Pathway } \\
\end{array}$ & Description & $\begin{array}{l}\text { Network } \\
\text { Change }\end{array}$ & Dynamic \\
\hline $\begin{array}{l}\text { TP 1: } \\
\text { Transformation } \\
\text { or 'Hybrid } \\
\text { Smart Grids' }\end{array}$ & $\begin{array}{l}\text { Centralised generation continues to dominate but } \\
\text { is complemented by renewables and small scale } \\
\text { distributed generation. Network infrastructure } \\
\text { remains principally defined at the national level. } \\
\text { Use of fossil fuels continues but Carbon Capture } \\
\text { and Storage ensures system is de-carbonised. }\end{array}$ & Medium & $\begin{array}{l}\text { Economic: the } \\
\text { market as an } \\
\text { organising } \\
\text { force }\end{array}$ \\
\hline $\begin{array}{l}\text { TP 2: } \\
\text { Reconfiguration } \\
\text { or 'Super Smart } \\
\text { Grid' }\end{array}$ & $\begin{array}{l}\text { Supranational/regional energy policy (e.g. EU) } \\
\text { results in the creation of a transnational super } \\
\text { gird that geographically diversifies away the } \\
\text { intermittency problem of renewables thereby } \\
\text { allowing for fully renewable-based system. }\end{array}$ & High & $\begin{array}{l}\text { Economic and } \\
\text { political: The } \\
\text { market and } \\
\text { international } \\
\text { collaboration } \\
\text { as organising } \\
\text { forces }\end{array}$ \\
\hline $\begin{array}{l}\text { TP 3: } \\
\text { Re-alignment or } \\
\text { 'Distributed } \\
\text { Smart Grids' }\end{array}$ & $\begin{array}{l}\text { This TP can be seen as the opposite response to } \\
\text { TP } 2 \text { to energy policy challenges (see Figure 5). } \\
\text { There is an increased emphasis on energy } \\
\text { conservation and local small-scale renewables } \\
\text { generation. The national network is replaced by } \\
\text { 'loosely coupled regional and local grids (micro } \\
\text { grids)' (Verbong and Geels, 2010). }\end{array}$ & High & $\begin{array}{l}\text { Localism: A } \\
\text { decentralised } \\
\text { and localised } \\
\text { response to } \\
\text { energy policy } \\
\text { challenges }\end{array}$ \\
\hline
\end{tabular}

Source: Adapted from Verbong and Geels (2010) and Battaglini et al., 2009

\subsection{The fusion of financial and energy system innovations}

The fusion of financial and energy system innovations raise a number of questions:

- The evolution of energy markets in a 'smart' energy system. What impact will an increased number of market participants have on counterparty risk? What are the micro-prudential considerations of such a change? How will market risk alter with 'prosumers', demand responsive consumers and increased energy storage? What will be the market liquidity effects of these changes and what role will new (e.g. energy services companies) and existing market intermediaries and institutions play in the new paradigm?

- Integration and contagion. What impact will the integration of energy markets geographically, across fuel types (due to technological change) and with financial markets have on the likelihood of financial contagion?

- Green energy speculative bubble. What is the likelihood of such a bubble? What fundamental drivers might trigger it: supply problems (e.g. evidence of peak oil); environmental concern (e.g. climate change); financial innovation (e.g. Exchange 
Traded Funds); technological innovation (e.g. breakthrough in electricity storage)? What impact would such a bubble have on the quantity and timing of energy infrastructure investment and energy technology choice (i.e. the interaction between primary energy financing and secondary energy markets)?

- Ex ante legislative mitigation of risks. How can institutions responsible for financial regulation/market governance (financial regulators, energy regulators, power exchanges etc) be adapted to be responsive to any new risks? Are the jurisdictional boundaries likely to be a limiting factor to risk mitigation in increasingly integrated markets?

From the above questions it is clear that it is useful to characterise risks as either emanating from primary (when a security is first issues raising cash for the firm issuing it) or secondary (the subsequent trading of the security) markets. Further it is clear that the response to a lot of the questions above will be moderated by the nature of the energy system of the future. As described above (Section 3.2) there are alternative visions of the energy system in the long run. These different visions and the distinction between primary and secondary market related risks are used in the mapping of future financial risks.

\section{Evolution and mapping of financial risks}

Underlying hypothesis of the research question is that financial risk will increase with marketisation and that the nature of that risk will depend on the nature of the future energy paradigm. Accordingly, prior to mapping the financial risk associated with fusion of innovation in both sectors, we explore the evolution of financial risk in the energy sector.

\subsection{Evolution of market risk in the energy}

This section highlights that as the energy sector is liberalised and increasingly 'marketised' energy utility companies will need to take on increasing amounts of market or systemic risk as a result of competitive pressures (Diaz-Rainey et al., 2011; Nwaeze, 2000). Nwaeze (2000) reports for US Energy Utilities that the shift towards competition leads to increased earnings variability as measure by return on assets (ROA) and return on equity (ROE). Further, the study found that there were significant increases in systematic risk around the dates of liberalisation reforms and negative abnormal returns around events associated with reform.

We provide a more up to date perspective of financial risk in the European energy system. We report for the period since liberalisation started in the mid 1990s time series of Value-at-Risk (VAR) derived from the total return data from a European energy utility index (Figure 3) and we calculate the average Beta for a group of 28 European utility companies (Figure 4). Both VAR and Beta are accepted measures related to market risk (Dowd, 2005).

Figure 3 indicated that the VAR from an investor perspective has increased over the period with peaks coinciding with the spike in oil prices in 2007/2008. Such a result would not be surprising if the analysis was on oil majors (Boyer and Filion, 2007) but is more surprising for energy utilities and might indicate that they are taking on considerable commodity price risk. Figure 4 indicates that systemic risk, as measured by 
Beta, has been on an upward trajectory for European utility companies since the bursting of the 'dot.com' bubble. This may, in the initial years post 2000, reflect the changing make-up of the market index with riskier technology firms becoming less prominent but this is unlikely to explain the rising trend in more recent years.

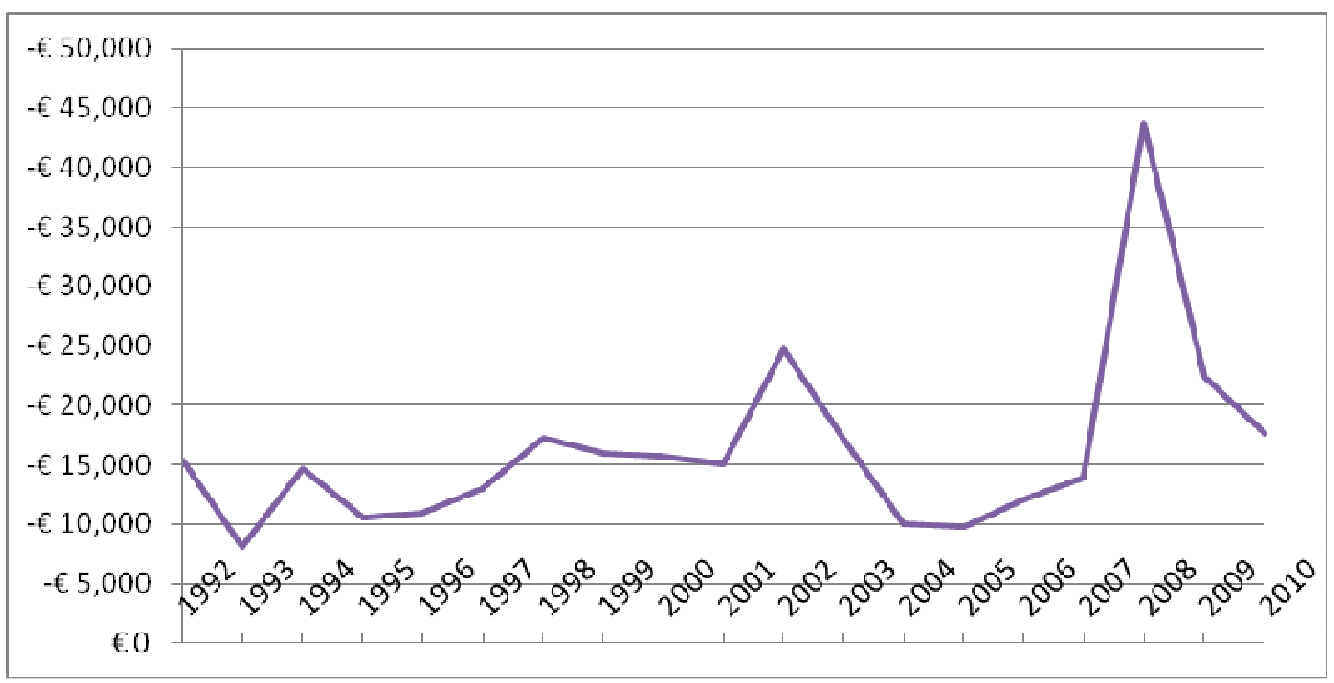

Figure 3 VAR of a hypothetical $€ 1,000,000$ investment in the STOXX 600 Utilities

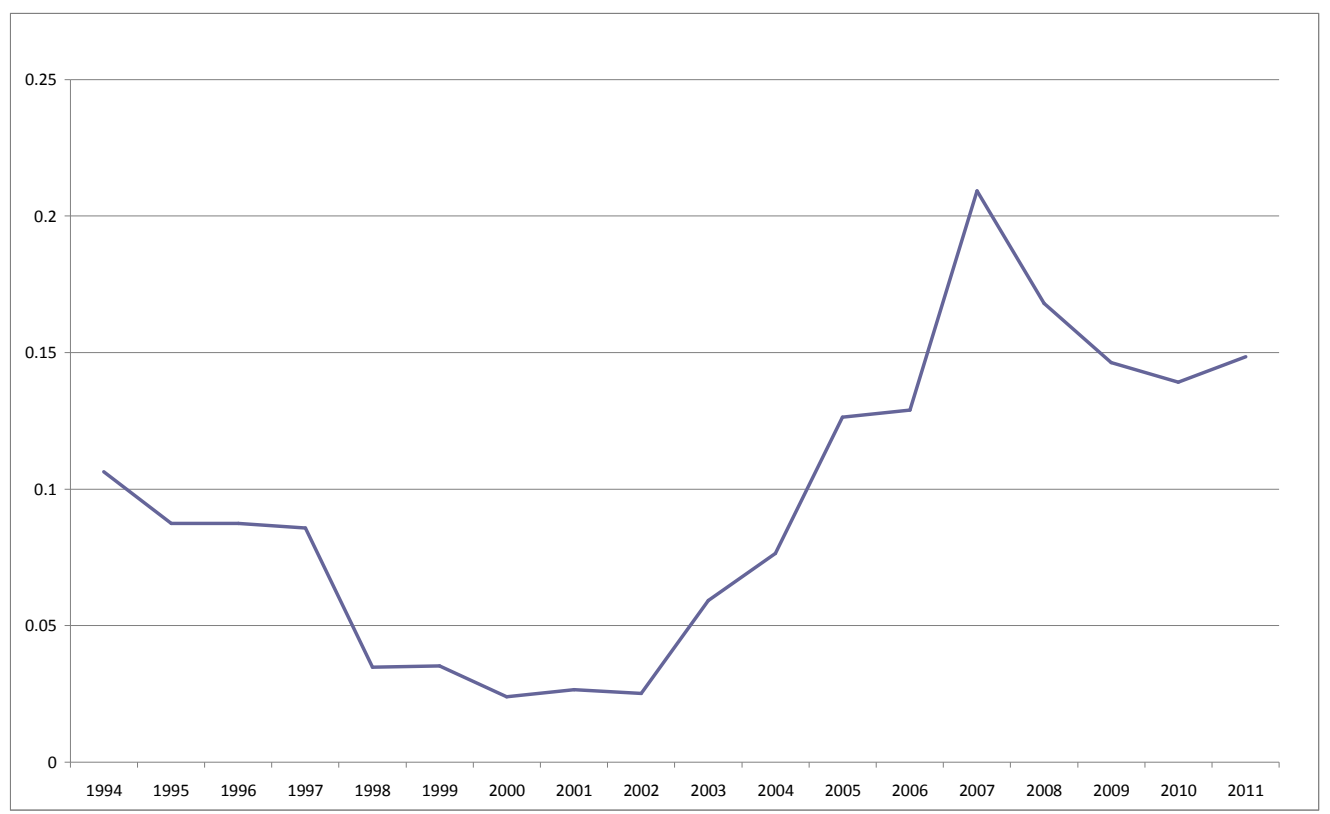

Figure 4 Average Beta of selected European utilities companies

Note: Calculated using the STOXX Europe Total Market Index, outliers removed 


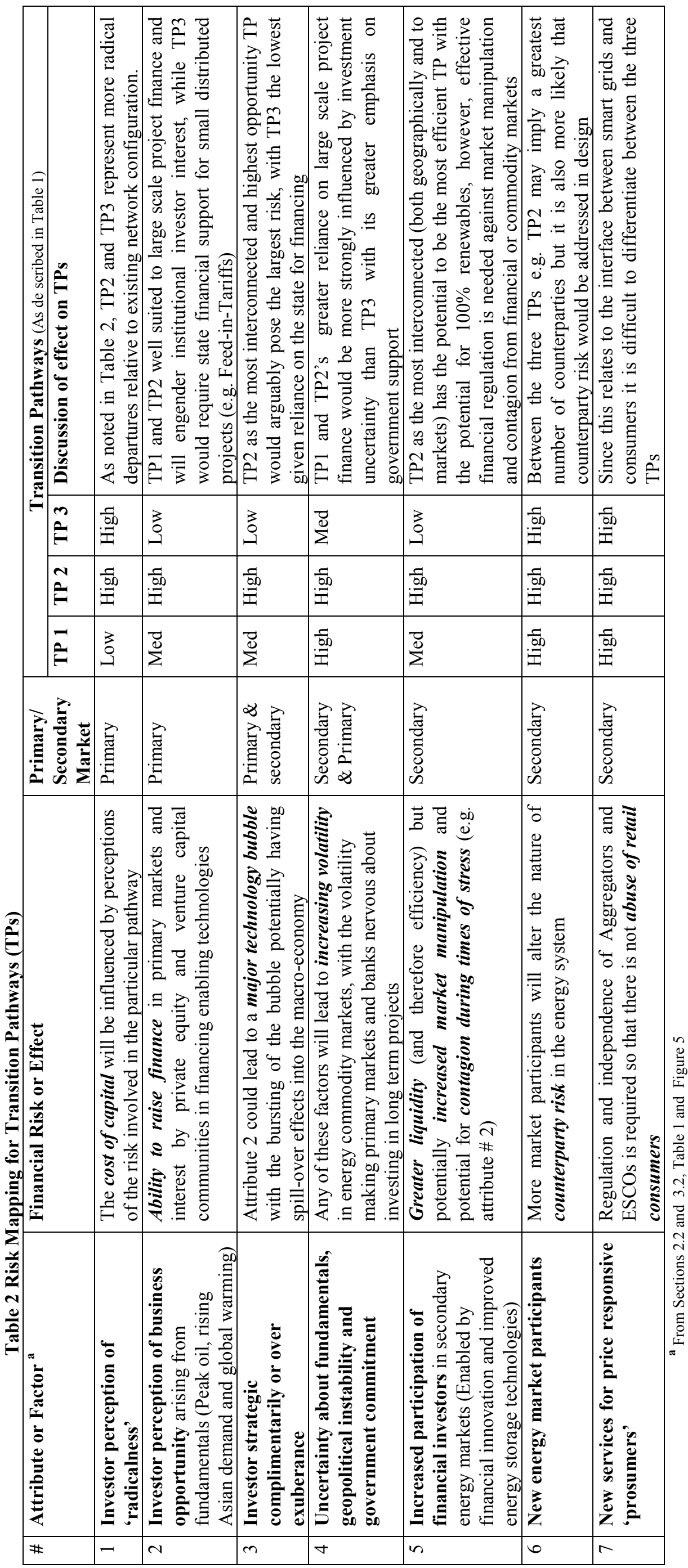




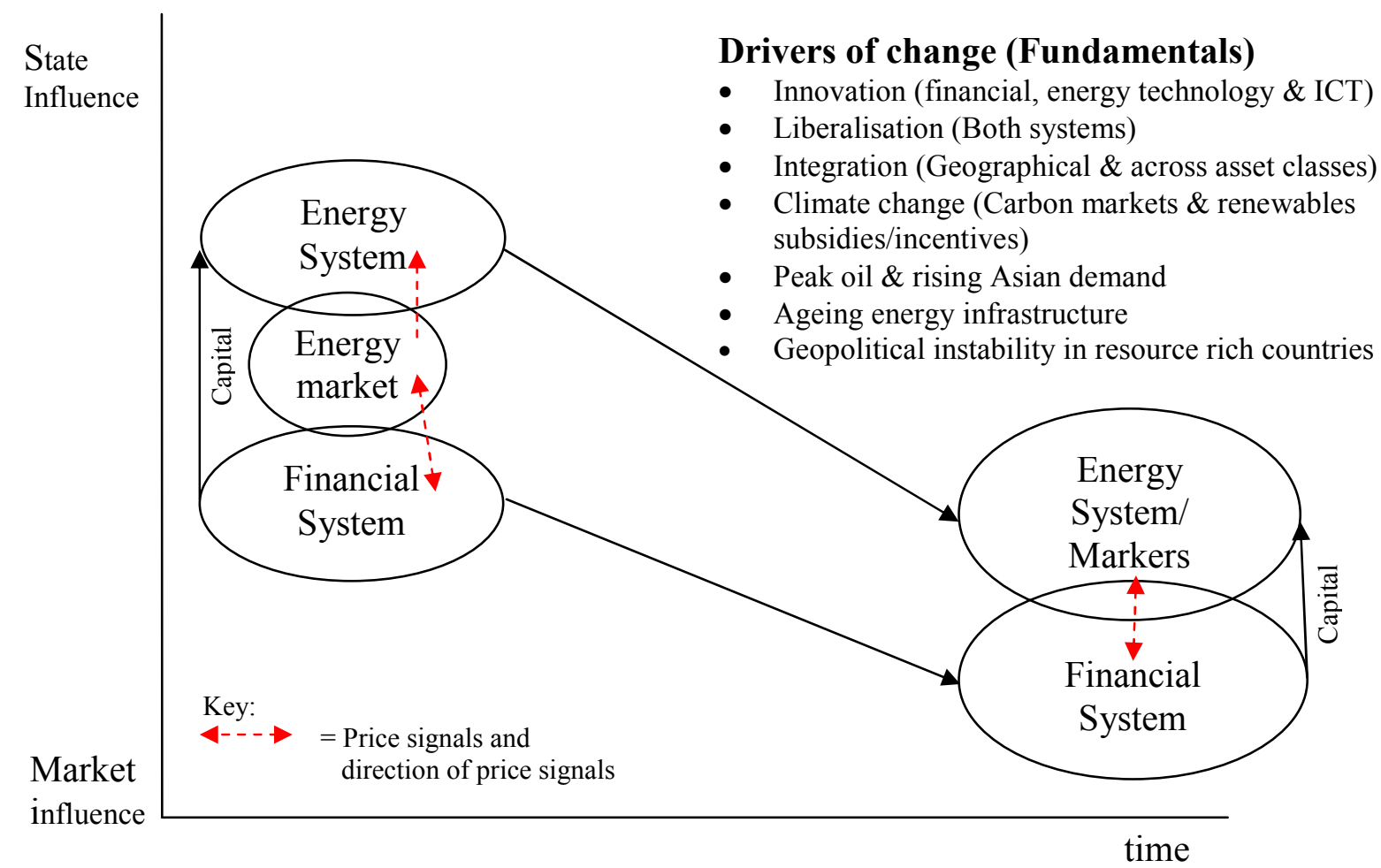

Figure 5 Evolution and Fusion of Energy and Financial Systems

\subsection{Mapping of risks to the financial and energy systems}

Figure 5 shows the overarching drivers of change and ultimate fusion of the energy and financial systems as both have been liberalised and integrated, while Table 2 maps financial risks associated with this transitions in terms of specific factors or attributes associated with the new energy paradigm. These financial risks are in turn rated (High, Medium, Low) in terms of their importance in the alternative visions of the energy system in the long run (see Section 3.2). Further, Table 2 specifies whether the risk relates to primary or secondary markets.

\section{Primary market risks}

Irrespective of transition pathway it is clear that a shift in energy paradigm is likely to occur as it is underpinned by strong fundamental changes (Figure 5) and that this shift will have broader implication to the economy and society. Such a transition is likely to lead to a 'major technology bubble' (See Table 2 and Perez, 2009). As noted earlier such bubbles are generally regarded as inevitable and are preferable to 'easy liquidity bubbles' as the former have positive transformative economic effects (See Section 2.2).

Further, Perez (2009, p.780) observes that a major technology bubble "regularly occurs midway along the process of assimilation of each technological revolution". If we date of beginning of the Telegestore project in Italy in 2000, the first large scale 
deployment of a critical enabling technology (Smart meters), as the beginning point of transition and the often cited 2050 date as the end of transition (Diaz-Rainey, 2009) we should expect the bursting of a related speculative bubble around 2025. Interestingly the 2000 commencement date also coincides roughly with mounting concerns about climate change between the second and third IPCC assessment and with a take-off in deployment of another important related technology, wind energy (See Davies and Diaz-Rainey, 2011).

Clearly the possibility and timing of a bubble could have major implications for the scale and timing of related investments. In some senses the 'strategic complementarity' that such a bubble could create and the impetus to investment that would follow would seem to be desirable from a public policy perspective up to a point. However, the bursting of such a bubble should not come as a surprise to policymakers and it might need mitigating actions to support future investment in energy sector transition and actions to dampen the effect of the bubble bursting on the broader economy and financial markets. One would hope that such action would not be overly loose monetary policy that leads to 'easy liquidity bubble' as in the case of the credit crunch of 2007 with its antecedents in the 'dot.com' mania of 2000 (Allen et al., 2009; Perez, 2009).

Of the three TPs (Table 2), TP 2 is the one most likely to cause a bubble since it implies the greatest business opportunity, reflecting a high risk reward trade-off. Investor interest in TP 3 is likely to be much lower which in turn may mean that enabling technologies that need to come to market do not develop as quickly as might be desired raising questions about the viability and speed of this transition pathway (See Table 2).

\section{Secondary market risks}

TP2 also stands out from an environmental and efficiency perspective as it offers the appealing prospect of $100 \%$ renewables generation and a stable system due to its centralised supergrid that diversifies away the intermittency problem of renewables (Diaz-Rainey, 2009; Roques et al. 2010). Further, due to its size, the energy market at its core is likely to be very liquid, with this liquidity increasing as it attracts financial investors in search of new asset classes to invest in (Table 2). These benefits come with the potential costs of;

- increases in volatility (especially if there is uncertainty about fundamentals)

- higher possibilities of market manipulation and speculation (facilitated by improved energy storage) and

- higher risks of financial contagion in times of financial stress. (See Table 2 and Section 2.1)

Finally, all three TPs pose new challenges with respect to potential abuse of retail customers and new challenges with respect to counterparty risk.

\section{Conclusions and policy implications}

The functioning of commodity and energy markets is currently receiving wide spread attention from a range of policymakers and regulators due to concern about speculation in these markets. This paper has highlighted some of the impacts that the marketisation of the energy sector is having on financial risk in the sector (Section 3.1). Moreover, the paper explored how innovation in the energy and finance sectors is likely to change the functioning of these markets and what associated risks may arise (Section 3.2.). Prior to 
this paper, most visions of the 'smart grid' of the future assume perfect (financial or energy) markets. From this a number of conclusions can be drawn.

At the most basic level this paper highlights the need to take a more sophisticated understanding of financial markets and financial innovation in the planning for the 'smart grid' of the future. Of the risks identified in the risk mapping process two categories of risk stand out as particularly requiring the attention of policymakers, namely (1) those related to increased risk of manipulation, speculation, contagion and volatility in the functioning of secondary energy markets and (2) those associated with the bursting of a 'major technology bubble' and its impact on financing energy sector transition through primary markets. In the latter case, some over exuberance may be desirable in accelerating investment but policymakers should not be surprised by the emergence of such a bubble (not least since we have predicted it will happen in 2025! See Section 4.2.) and should be prepared to intervene in a way so as not to repeat the mistakes of recent years i.e. with the response to a 'major technology bubble' (the 'dot.com' mania) contributing to the creation of an 'easy liquidity bubble' (the 'credit crunch') (see Allen et al. 2009; Perez, 2009).

The former set of risks highlights the need for effective financial regulation of energy markets as they evolve and are increasingly integrated with conventional financial markets. Thus, there is clearly a need for an analysis of the evolving approach to the monitoring of energy markets within the context of these risks. From an EU perspective, this needs to consider the new European architecture for financial regulation which includes the establishment of new institutions such as European Systemic Risk Board and European Securities and Markets Authority. Further, from the EU energy policy side, the latest push for further energy market integration has created a pan-European body (Agency for the Cooperation of Energy Regulators) with purportedly a market monitoring role (See Diaz-Rainey et al., 2011; EU Commission, 2010).

A number of limitations in our analysis highlight further research needs, namely; (1) to econometrically test the factors driving the changes depicted in Figures 3 and 4 and control for confounding effects; (2) to quantify the risks mapped in Table 2 perhaps through a survey of experts; and (3) to explore geographical differences since the current risk mapping has been premised on the basis that further energy system integration is possible (as in the case of Europe and North America) but this is clearly not applicable in countries like New Zealand.

Notwithstanding the research needs already outlined the main implications in this respect are, however, related to science policy in this area; namely that when commissioning research into 'smart grids', funders need to ensure financial innovation and associated risks are incorporated in their assessments. In particular, formal models of energy systems transitions (such as the UK MARKAL-Macro Model used by UK Energy Research Centre) need to incorporate a more nuanced understanding of financial risks and the relationship between innovation and financial and commodity markets. Other formal modelling that could follow on from this work might include: (1) agent based simulations of the interaction of energy and conventional financial markets in times of financial stress (see Allen et al., 2009; Diaz-Rainey et al., 2011); (2) extend portfolio theory based energy planning modelling (Awerbuch, 2006) to incorporate technological change and forward projections of energy market volatility (See Table 2); (3) modelling and empirically testing the assertion by Perez $(2009$, p. 780$)$ that speculative bubbles burst halfway through a paradigm shifts using established innovation diffusion models (See Davies and Diaz-Rainey, 2011). 


\section{Acknowledgments}

We thank participants at the ISPIM/Tudor 'Innovation for Financial Services Summit' (21-23 September 2011, Luxembourg) for helpful comments. The usual disclaimer applies.

\section{References}

Allen, F., Babus A., Carletti, E., (2009). 'Financial Crises: Theory and Evidence', Annual Review of Financial Economics, 2009, 1:1, 97-116.

Allen, F., Gale, D., (2004). 'Competition and Financial Stability', Journal of Money, Credit and Banking, 36:3, 453-480.

Anderson, P., Tushman, ML., (1990). 'Technological Discontinuities and Dominant Designs: A Cyclical Model of Technological Change', Administrative Science Quarterly, 35:1, 604-633.

Awerbuch, S., (2006). 'Portfolio-based Electricity Generation Planning: Policy Implications for Renewable and Energy Security', Mitigation and Adaptation Strategies for Global Change, 11, 693-710.

Baig, T., Goldfajn, I., (1999). 'Financial Market Contagion in the Asian Crisis', International Monetary Fund Staff Papers, 46:2, 167-195.

Battaglini, A., Lilliestam, J., Haas, A., Patt, A., (2009). 'Development of SuperSmart Grids for a more efficient utilisation of electricity from renewable sources', Journal of Cleaner Production, 17, 911-918.

Bordo, M., Eichengreen, B., Klingebiel, D., Martinez-Peria MS., (2001). 'Is the Crisis Problem Growing More Severe?', Economic Policy, 16:32, 53-82.

Boyer, MM., Filion, D., (2007). 'Common and Fundamental Factors in Stock Returns of Canadian Oil and Gas Companies'. Energy Economics, 29, 428-53.

Buyuksahin, B., Harris, JH., (2011). 'Do Speculators Drive Crude Oil Futures Prices?', The Energy Journal, 32:2, 167-202.

Davies, SW., Diaz-Rainey, I, (2011). 'The patterns of induced diffusion: Evidence from the international diffusion of wind energy', Technological Forecasting and Social Change, 78, 1227-1241.

Diaz-Rainey, I., Siems, MM., Ashton, JK., (Forthcoming 2011). 'The Financial Regulation of Energy and Environmental Markets', Journal of Financial Regulation and Compliance, 19:4.

Diaz-Rainey, I., (2009). 'Long term energy trends - Where will we be in 2050?', Loyola de Palacios Policy Paper Series, EUI, Florence.

Dosi, G., (1982). 'Technological Paradigms and Technological Trajectories', Research Policy, 11:3, 147-162.

Dosi, G., Nelson. R., (1994) 'An introduction to evolutionary theories in economics', Journal of Evolutionary Economics, 4, 153-172.

Dowd, K., (2005). Measuring Market Risk. $2^{\text {nd }}$ ed. Chichester: Wiley \& Sons Ltd.

EU Commission, (2011). Energy 2020: A strategy for Competitive, Sustainable and Secure Energy, Directorate-General for Energy and Transport, Brussels.

EU Commission, (2010). Proposal for a Regulation of the European Parliament and of the Council on Energy Market Integrity and Transparency, COM(2010) 726/3. 
Fransman, M., (2004). 'The Telecoms Boom and Bust 1996-2003 and the Role of Financial Markets', Journal of Evolutionary Economics, 14, 369-406.

Foxon, TJ., Hammond, GP., Pearson, PJG., (2010). 'Developing transition pathways for a low carbon electricity system in the UK', Technological Forecasting and Social Change, 77, 1203-1213.

Galbraith, JK., (1954). The Great Crash of 1929. London: Penguin Books.

Garber, PM., (1990). 'Famous First Bubbles', Journal of Economic Perspectives, 4:2, 3554.

Geels, FW., Schot, J., (2007). 'Typology of sociotechnical transition pathways', Research Policy, 36, 399-417.

Goddard, J., Molyneux, P., Wilson, JOS., (2009). 'The financial crisis in Europe: evolution, policy responses and lessons for the future', Journal of Financial Regulation and Compliance, 17:4, 365-380.

Haldane, A., (2010). Patience and Finance, Paper for the Oxford China Business Forum by Executive Director for Financial Stability, Bank of England, available at: www.bankofengland.co.uk

Hendershott, T., Jones, CM., Menkveld, AJ., (2011). 'Does Algorithmic Trading Improve Liquidity?', Journal of Finance, 66:1, 1-33.

Jørgensen, U., (2005). 'Energy sector in transition - technologies and regulatory policies in flux', Technological Forecasting and Social Change, 72:6, 719-731.

Kam, J., (2006). 'No Pain, No Gain: Rethinking the Telecoms Crash', Technology Analysis and Strategic Management, 18:5, 497-514.

Levin, C., Coleman, N., (2007). Excessive Speculation in the Natural Gas Market, Staff Report, United States Senate, Permanent Subcommittee on Investigations.

Lombardi, M., Van Robays, I., (2011). 'Do Financial Investors Destabilize the Oil Price?', ECB Working Paper Series, no. 1346, June.

Nwaeze, ET., (2000). 'Deregulation of the Electric Power Industry: The Earnings, Risk, and Return Effects', Journal of Regulatory Economics, 17:1, 49-67.

O'Hara, M., Ye, M., (2011). 'Is Market Fragmentation Harming Market Quality?', Journal of Financial Economics, 100, 459-474.

Perez, C., (2010). 'Technological Revolutions and Techno-Economic Paradigms', Cambridge Journal of Economics, 34, 185-202.

Perez, C., (2009). 'The Double Bubble at the turn of the Century: Technological Roots and Structural Implications', Cambridge Journal of Economics, 33, 779-805.

Roques, F., Hiroux, C., Saguan, M., (2010) 'Optimal wind power deployment in Europe-A portfolio approach', Energy Policy, 38:7, 3245-3256.

Turner, A., Farrimond, J., Hill J. (2011) 'The Oil Trading Markets, 2003 - 2010: Analysis of market behaviour and possible policy responses', Oxford Institute for Energy Studies WPM 42.

US DOE, (2009). Smart Grid System Report, US Department of Energy, July.

Van Horne, JC. (1985) 'Of Financial Innovations and Excesses', Journal of Finance, $40: 3,620-631$.

Verbong, GPJ., Geels, FW., (2010). 'Exploring sustainability transitions in the electricity sector with socio-technical pathways', Technological Forecasting and Social Change, $77,1214-1221$.

Valocchi M., Juliano, J., Schurr, A., (2010). Switching Perspective - Creating new business models for a changing world of energy, IBM Institute for Business Value Executive Report, March. 